Revue bibliographique pour le domaine irano-aryen

\title{
David Stronach, Felix Ter-Martirosov, Alina Ayvazian, William Collins, Catherine Demos, Soroor Ghanimati. Iranica Antiqua, 45
}

\section{Rémy Boucharlat}

\section{(2) OpenEdition}

1 Journals

\section{Édition électronique}

URL : http://journals.openedition.org/abstractairanica/40420

DOI : 10.4000/abstractairanica.40420

ISSN : 1961-960X

Éditeur :

CNRS (UMR 7528 Mondes iraniens et indiens), Éditions de l'IFRI

\section{Édition imprimée}

Date de publication : 1 décembre 2013

ISSN : 0240-8910

\section{Référence électronique}

Rémy Boucharlat, « David Stronach, Felix Ter-Martirosov, Alina Ayvazian, William Collins, Catherine Demos, Soroor Ghanimati. Iranica Antiqua, 45 », Abstracta Iranica [En ligne], Volume 32-33 | 2013, document 120, mis en ligne le 01 juillet 2016, consulté le 04 octobre 2020. URL : http:// journals.openedition.org/abstractairanica/40420 ; DOI : https://doi.org/10.4000/abstractairanica. 40420

Ce document a été généré automatiquement le 4 octobre 2020.

Tous droits réservés 


\title{
David Stronach, Felix Ter- Martirosov, Alina Ayvazian, William Collins, Catherine Demos, Soroor Ghanimati. Iranica Antiqua, 45
}

\author{
Rémy Boucharlat
}

\section{RÉFÉRENCE}

David Stronach, Felix Ter-Martirosov, Alina Ayvazian, William Collins, Catherine Demos, Soroor Ghanimati. Iranica Antiqua, 45, 2009, p. 181-206, 8 Pl. coul.

1 Première saison de fouilles conduites en 2007 sur le site d'Erebuni, qui se trouve dans la ville de Erevan, par l'université de Berkeley et l'université d'Etat de Erevan. Fouillé pendant des années durant l'époque soviétique, le site est l'une des capitales du royaume urartéen au VIII ${ }^{\mathrm{e}}$ et $\mathrm{VII}^{\mathrm{e}}$ s. av. J.-C. Peu à peu, pourtant, le doute s'est installé sur la date de la salle hypostyle dite Apadana par ressemblance avec les salles de Suse et Persépolis. Son antériorité par rapport à celles-ci n'est plus prouvée. L'un des objectifs du nouveau programme est précisément de mieux étudier la période urartéenne tardive ou déjà post-urarténne qui fait la transition du royaume d'Urartu à la période achéménide. Les fouilles sur la Colline sud apportent peu à peu des indices sur cette période charnière. 


\section{AUTEURS}

RÉMY BOUCHARLAT

CNRS, Lyon 